Journal of Contemporary Research in Business, Economics and Finance

ISSN: 2641-0265

Vol. 3, No. 4, pp. 144-157.

2021

Publisher: Learning Gate

DOI: 10.33094/26410265.2021.34.144.157

(C) 2021 by the authors; licensee Learning Gate

\title{
The Dynamic Impact of Public External Debt on Capital Formation in Sub- Saharan Africa: The Pooled Mean Group Approach
}

\author{
Chukwunenye N. Kocha \\ Department of Banking \& Finance, Rivers State University, Nkpolu, Port Harcourt, Nigeria. \\ Email:nenekocha1@gmail.com \\ Marshal Iwedi* \\ Department of Banking \& Finance, Rivers State University, Nkpolu, Port Harcourt, Nigeria. \\ Email:marshaliwedi22@gmail.com (*CorrespondingAuthor) \\ James Sarakiri \\ Department of Banking and Finance, Macpherson University, Ogun State, Nigeria \\ Email: sarakirijames@gmail.com
}

Received: 28 April 202 1; Revised: 2 November 202 1; Accepted: 29 November 202 1; Published: 23 December 2021

\begin{abstract}
The increasing reliance on public external debt stocks in Africa and other developing countries has raised the question of debt sustainability, especially in the face of Covid-19, which has forced many counties (both developed and developing) into an unforeseen and unplanned recession. This study contributes to the literature on debt sustainability by examining the effect of public debt on capital formation in Sub-Saharan Africa (SSA) from 2000 to 2008 using the pooled mean group estimation approach. The debt variables considered are external debt stock, debt service on external debt, and interest payment on external debt. Consistent with the overhang theory, our results show that increasing external debt stock and interest payment on external debts only have a marginal impact on capital formation in the short run and exerts a serious negative effect in the long run. Our results also show that debt service burden has a positive effect on gross fixed capital formation in the long run. Therefore, we argue that despite being faced with a huge debt service burden resulting from large external debt stock, SSA countries are not neglecting investments in critical infrastructures needed to drive economic growth. However, we recommend that increasing government revenue base, minimizing economic waste associated with public expenditure, and intensifying negotiations for debt relief may be a plausible way out.
\end{abstract}

Keywords: Public debts, Gross fixed capital formation, Pooled mean group.

\section{Introduction}

With the increasing public debt level in Africa, which has further raised the question of debt sustainability in developing and low-income countries, it has become more imperative to reconsider the impact of public debt on Sub-Saharan African economies. The debt sustainability issue has also assumed an interesting dimension in the face of the Covid-19 pandemic, which has not only led to a drastic increase in public debts across world countries but has also forced many counties (both developed and developing) into an unforeseen and unplanned recession. In its June 2020 world economic outlook update, the International Monetary Fund (IMF) warned that the adverse impact of Covid-19 on lowincome counties is particularly severe, jeopardizing the considerable progress recorded so far in the global fight against extreme poverty since the 1990s. Also, the United Nations, in its October 2020 report on the world economic situation and prospects, contends that rising debt levels and debt 
servicing burden would force developing countries to cut investment in critical economic sectors such as health, education, technology, physical and digital infrastructure, and energy transition.

However, there are contrasting theoretical views regarding the impact of public debt on the economy. Both debt overhang theory (Krugman, 1988; Reinhart, Reinhart, \& Rogoff, 2012) and crowding out theory (Carlson \& Spencer, 1975) predict that increasing public debt level has a negative economic implication. Increasing public debt level reduces the incentive for private investment owing to fears of high future taxes and/or possible debt crises (Chowdhury, 2001), and may also crowd out both private and public investments through interest rate (Ahmed \& Miller, 2000) and debt service (Bhattacharya \& Clements, 2004). By contrast, the Keynesian model predicts that a rising public debt level is beneficial to the economy as it helps to employ idle resources which lead to higher productivity and output. Further, the Ricardian equivalence theory contends that rising public debt is inconsequential since government deficits can be financed by increasing the public debt stock or by raising taxes. The above begs the question, "To what extent does rising public debt stock affect real economic variables in developing countries?" This paper seeks to provide an empirical answer to this question by considering the extent to which public debt affects real economic activities in Sub-Saharan African countries. In particular, the study employs the pooled mean group (PMG) methodological framework to analyze both the long-run and short-run impacts of three public debt measures, namely external debt stock, debt service on external debts, and interest payments on external debts, using yearly data on twelve Sub-Saharan countries over the period from 2000 to 2018.

This paper contributes to the literature in three distinct ways. First, the use of the pooled mean group (PMG) regression approach allows us to examine both the short-run and long-run impacts of public debt on capital formation, which is novel in the literature on Sub-Saharan Africa. To our knowledge, this dynamic panel framework has not been utilized previously to analyze the impact of public debt in the context of Sub-Saharan Africa. Second, we focus on 12 Sub-Saharan African countries from 2000 to 2018, which is large enough to examine both the short-run and long-run implications of the increasing debt burden, therefore adding to the current debate on debt sustainability in Africa and other developing countries. Finally, compared to previous studies, which largely focus on economic growth, our focus is on capital formation, which has been identified as one of the main channels through which changes in public debt can affect real economic activities. According to Nautet \& Van Meensel (2011), an increase in public debt would lead to an increase in interest charges, which would, in turn, reduce productive public expenditure (e.g., investment in public infrastructure), leading to lower labor productivity, and, ultimately, to lower national output. Also, Islam \& Hasan (2007) found that public debt has a positive effect on inflation, which, in turn, has a negative effect on both capital formation and real output. The rest of the paper is organized as follows: Section 2 discusses the existing literature on the link between public debt and macroeconomic variables, including capital formation; Section 3 discusses the research methodology; Section 4 presents the empirical results; and Section 5 concludes.

\section{Literature Review}

\subsection{Theoretical Foundation}

The theoretical analysis of the impact of public debt on economic activities is well established in the literature. However, some of the influential theories that explain the role of public debt in the economy (e.g., Keynesian theory, debt overhang theory, crowding out theory, and Ricardian equivalence theory) present contrasting arguments. The traditional Keynesian IS-LM model argues that an increase in public debt due to an increase in government expenditure would have an expansionary effect on the economy through an increase in income, and transaction demand for money and prices (Islam \& Hasan, 2007). According to Islam \& Hasan (2007), the expansionary effect of public debt on capital accumulation can also be viewed in the context of Koyck's flexible accelerator model, which contends that the level of investment is determined by changes in output. By contrast, the monetarists used the crowding out effect narrative to explain the impact of increasing debt level on the economy. They argue that using public debt to finance fiscal deficit would displace or crowd out private investment, thereby 
retarding economic growth. According to De Leeuw \& Holloway (1983), the crowding out effect theory of public debt holds, especially when the stock of government securities become substitutes for capital stock in the portfolios comprising public assets. Similarly, the debt overhang theory (Krugman, 1988) argues that public debts have a negative economic implication when the stock of debt crosses a certain threshold. A large debt level reduces the incentive for private investment owing to fears of high future taxes and/or possible debt crises (Chowdhury, 2001). This implies that increasing public debt has a negative effect on economic growth through a decrease in investment.

However, the Ricardian equivalence theory contends that using public debt to finance fiscal deficit would not affect private consumption and investment since debt financing is nothing but a postponement of taxation (Kazmi, 2001). This theory, which emphasizes the neutrality of public debt, is based on the premise that people see debt issuance as a signal that the government intends to increase future tax, so they deliberately reduce their current consumption to purchase government securities. The equivalence theory especially holds if the present value of the future tax stream remains constant.

The literature also distinguishes between the short-term and long-term impacts of public debt. According to Nautet \& Van Meensel (2011), public debt has a negative short-term effect on the economy, while its long-term impact is positive. This distinction has also been confirmed in the empirical literature as several studies have reported evidence of both short-term and long-term effects of public debt. However, previous studies have reported mixed evidence regarding the direction of the impact of public debt on economic activities. While some studies found evidence that is consistent with Nautet \& Van Meensel (2011), others reported evidence suggesting that public debt has a positive shortterm impact on the economy, while its long-term effect is harmful.

\subsection{Review of Empirical Studies}

Chowdhury (2001) employed the mixed fixed and random (MFR) model to examine the causal link between public debt and economic growth for two separate country groups: HIPC (heavily indebted poor countries) and non-HIPC. The study covers the period from 1982 to 1999, and the sample comprises 210 observations for the HIPC group and 150 observations for the non-HIPC group. The MFR results show, among other things, that all examined public debt measures have a negative and significant causal impact on economic growth in the two country groups. In this paper, we empirically examine the effects of government debt on interest rate, price, output and capital formation in the USA during the post-war period. Using cointegration methodology supplemented with variance decompositions and impulse response functions, the study found a long-run equilibrium as well as a strong feedback relationship between real debt and real capital formation. The results also indicate that public debt increases inflation with adverse effects on capital formation and real output, which broadly support the views of monetarists and partially of the neo-Ricardian economists.

Islam \& Hasan (2007) examined the impact of public debt on macroeconomic variables, such as interest rate, prices, capital formation and output, over the period from 1946 to 2000 using the vector error correction model (VEC) and its associated variance decomposition and impulse response function. However, the empirical analysis is based on real variables rather than the nominal variables used in most previous analyses. They found evidence of at least one cointegrating link among real capital stock, real output, and real debt. Also, contrary to the Keynesian theoretical stance, their results show that public debt has a positive effect on inflation, which, in turn, has a negative effect on both capital formation and real output. Akram (2011) employed the ARDL model to examine both the short-run and long-run economic implications of public debt in Pakistan from 1972 to 2009. Specifically, the study considers the impact on per capita GDP and investment (gross capital formation ratio to GDP) of three public debt measures, namely external debt-to-GDP, domestic debt-to-GDP, and debt service-to-GDP. Consistent with the debt overhang theory, the results provided evidence that external debt has a negative effect on both real GDP per capita and gross capital formation in both the short-run and the long-run. However, domestic debt has a significant negative impact on investment but its impact on 
economic growth is not significant. Finally, while debt servicing has a significant negative impact on per capita GDP, its impact on investment is not significant.

Ahamefula (2015) examined both static and dynamic relationships between public debt and infrastructural provision in Nigeria from 1981 to 2012 using multiple regression and Granger causality tests. They found that domestic debt has a positive relationship with gross fixed capital formation, while the relationship between external debt and gross fixed capital formation is negative. They also found that while causality runs from gross fixed capital formation to domestic debt, there is no evidence of a causal relationship between external debt and gross fixed capital formation.

Baum, Checherita-Westphal, \& Rother (2012) investigated the link between public debt and economic growth in the Euro area using the dynamic threshold panel framework. They used a panel sample comprising data from 12 countries from 1990 to 2010 . They found that public debt has a positive and significant short-run impact on economic growth, which reduces to zero and becomes insignificant when the debt-to-GDP ratio increases to more than $67 \%$. Also, their results show that when the debtto-GDP ratio is above $95 \%$, additional debt has a negative effect on the economy, and there is increased pressure on the long-term interest rate when debt-to-GDP ratio is above $70 \%$.

Bal (2014) employed the structural VAR to analyze the effects on interest, capital formation and output of public debt in India using quarterly data from 1998Q4 to 2012Q4. The results show that public debt exerts a positive impact on both capital formation and output but exerts a negative effect on interest rate. Also, the results show that in the third period, public debt explains approximately $16 \%$ of the variation in interest rate, and approximately $36 \%$ and $30 \%$ of the variation in gross fixed capital formation and 30\% output, respectively. Mencinger, Aristovnik, \& Verbic (2014) examined the impact of increasing public debt stocks on economic growth focusing on $25 \mathrm{EU}$ sovereign member states from 1980 to 2010. However, the sample was divided into two groups: old member states, which covers the period from 1980 to 2010; and new member states, which covers the period from 1995 to 2010 . They found that while public debt had a non-linear effect on economic growth for all samples, the threshold debt level beyond which its effect changes from positive to negative differs between the two sample groups (between $80 \%$ and $94 \%$ for old member states, and between $53 \%$ and $54 \%$ for new member states). Kwoba \& Kosimbei (2015) employed the random effects empirical framework to analyze the impact on economic growth of public debts in the East African region using yearly data for 24 years from 1990 to 2013. The effects of gross fixed capital information and labor force participation rate are also incorporated in the growth model. Their findings, which are consistent with the debt overhang theory, indicate that public external debt has a negative and significant effect on GDP per capital growth rate, while the effect of gross fixed capital formation is positive and highly significant. However, the effect of labor force participation is not statistically significant. Abdullahi, Hassan, \& Bakar (2016) investigated the impact of external debt on capital formation and economic growth in Nigeria using yearly time series data from 1980 to 2013. Using the ARDL model, they found that while external debt stock has a negative effect on capital formation both in the short run and long run, the short-run effect of external debt service is almost zero. These results hold controlling for the impacts of interest rate and savings. Okoye, Modebe, Erin, \& Evbuomwan (2017) considered the effect of external debt on economic growth in Nigeria from 1981 to 2015 using both OLS and GLS methods. The effects of gross fixed capita formation, exchange rate and inflation rate on growth were also examined. Their findings, which are consistent across methods, show that external debt, exchange rate and inflation rate all have a positive effect on economic growth, while the effect of gross fixed capital formation is negative but not statistically significant. Using the ARDL methodological framework, Kharusi \& Ada (2018) considered the impact of government borrowing on economic growth in Oman for the period from 1990 to 2015. Consistent with the overhang theory and crowding out effect hypothesis, they found that external debt has a negative and significant impact on economic growth. Their findings also indicated that gross fixed capital formation and economic growth are positively related. Thao (2018) investigated the public debtgrowth linkage in six ASEAN countries: Malaysia, Philippines, Singapore, Indonesia, Thailand, and Vietnam, over the period from 1995 to 2015 . The study also considered the effects of gross fixed capital 
formation, FDI, and real effective exchange rate on real GDP per capita growth rate. Contrary to most previous studies, the results, based on the panel dynamic GMM framework, show that public debt has a positive and significant effect on growth. The results also show that both gross fixed capital formation and FDI have significant positive effects on the ASEAN economies.

Filip (2019) employed the dynamic panel data framework to examine the determinants of public debt focusing on European countries. The empirical analysis is based on panel data for 28 European countries over the period from 1995 to 2017. The findings show that gross fixed capital formation is among the significant factors that affect public debt. Other factors that determine public debt are real GDP growth, trade balance and FDI inflows. Whajah, Bokpin, \& Kuttu (2019) used the static fixed effect regression model to investigate the empirical relationship between public debt, government size, and inclusive growth using panel data on all 54 African countries from 2000 to 2016. The empirical model includes trade openness, gross fixed capital formation, inflation, labor productivity and population growth as control variables. Consistent with the debt overhang theory, they find, amongst others, that public debt has a negative effect on inclusive growth.

\section{Methodology}

\subsection{Data and Variables}

Table 1.

Descriptive statistics for the pooled data and the individual countries.

\begin{tabular}{|c|c|c|c|c|c|c|}
\hline Country & Variable & $\bar{x}$ & $\sigma$ & $S$ & $\bar{K}$ & obs. \\
\hline \multirow[t]{4}{*}{ Botswana } & GFCF/GDP & 30.00 & 3.37 & 0.21 & 1.93 & 19 \\
\hline & EXTDGDP & 8.32 & 3.60 & -0.03 & 1.58 & 19 \\
\hline & DSGDP & 0.79 & 0.37 & 0.87 & 2.97 & 19 \\
\hline & INTPGDP & 0.18 & 0.06 & 0.45 & 2.44 & 19 \\
\hline \multirow[t]{4}{*}{ Côte d'Ivoire } & GFCF/GDP & 13.50 & 5.23 & 0.82 & 2.08 & 19 \\
\hline & EXTDGDP & 44.72 & 22.90 & 0.13 & 1.59 & 19 \\
\hline & DSGDP & 3.65 & 1.95 & 1.61 & 5.50 & 19 \\
\hline & INTPGDP & 1.10 & 1.12 & 2.56 & 9.28 & 19 \\
\hline \multirow[t]{4}{*}{ Gabon } & GFCF/GDP & 25.74 & 4.15 & 0.72 & 2.67 & 19 \\
\hline & EXTDGDP & 35.13 & 16.52 & 0.46 & 2.18 & 19 \\
\hline & DSGDP & 4.94 & 3.67 & 1.99 & 7.16 & 19 \\
\hline & INTPGDP & 1.55 & 0.93 & 0.91 & 2.76 & 19 \\
\hline \multirow[t]{4}{*}{ Ghana } & GFCF/GDP & 21.78 & 5.89 & -0.29 & 1.77 & 19 \\
\hline & EXTDGDP & 40.42 & 34.95 & 1.01 & 2.41 & 19 \\
\hline & DSGDP & 2.83 & 2.32 & 1.45 & 4.52 & 19 \\
\hline & INTPGDP & 0.97 & 0.69 & 1.66 & 5.97 & 19 \\
\hline \multirow[t]{4}{*}{ Kenya } & GFCF/GDP & 18.94 & 1.92 & 0.24 & 2.27 & 19 \\
\hline & EXTDGDP & 24.91 & 7.60 & 0.32 & 1.54 & 19 \\
\hline & DSGDP & 2.18 & 1.20 & 0.75 & 2.19 & 19 \\
\hline & INTPGDP & 0.61 & 0.31 & 0.62 & 2.09 & 19 \\
\hline \multirow[t]{4}{*}{ Malawi } & GFCF/GDP & 14.37 & 4.21 & 0.95 & 2.33 & 19 \\
\hline & EXTDGDP & 46.52 & 44.20 & 1.19 & 3.03 & 19 \\
\hline & DSGDP & 1.26 & 0.84 & 1.35 & 4.58 & 19 \\
\hline & INTPGDP & 0.42 & 0.30 & 1.35 & 4.26 & 19 \\
\hline \multirow[t]{4}{*}{ Mauritius } & GFCF/GDP & 21.39 & 2.72 & -0.62 & 2.22 & 19 \\
\hline & EXTDGDP & 7.33 & 2.64 & 0.41 & 1.84 & 19 \\
\hline & DSGDP & 18.74 & 10.81 & 1.13 & 4.37 & 19 \\
\hline & INTPGDP & 1.31 & 0.79 & 1.02 & 2.33 & 19 \\
\hline
\end{tabular}


In this study, we use panel data comprising twelve Sub-Saharan countries covering the period from 2000 to 2019. The countries are Botswana, Côte d'Ivoire, Kenya, Ghana, Gabon, Mauritius, Malawi, Nigeria, South Africa, Rwanda, Uganda and Tanzania. While capital formation is proxied by gross fixed capital formation, the debt variables considered are external debt stock, debt service on external debt, and interest payment on external debt. The dataset were sourced from the world development indicators (WDI), while all analyses were conducted in EViews.

Table 1 shows the summary of statistics for the individual countries and the pooled data. Figures 1 to 4 show the time series plots for the sampled countries.

Table 2.

Descriptive statistics for the pooled data and the individual countries (Cont'd).

\begin{tabular}{|c|c|c|c|c|c|c|}
\hline Country & Variable & $\overline{\bar{x}}$ & $\sigma$ & $S$ & $K$ & Obs. \\
\hline \multirow[t]{4}{*}{ Nigeria } & GFCF/GDP & 20.83 & 6.27 & 0.56 & 2.06 & 19 \\
\hline & EXTDGDP & 10.76 & 14.25 & 1.21 & 2.88 & 19 \\
\hline & DSGDP & 1.27 & 1.34 & 1.41 & 4.28 & 19 \\
\hline & INTPGDP & 0.39 & 0.67 & 2.74 & 10.12 & 19 \\
\hline \multirow[t]{4}{*}{$\mathrm{SA}$} & GFCF/GDP & 18.72 & 2.25 & 0.05 & 2.43 & 19 \\
\hline & EXTDGDP & 10.45 & 5.61 & 0.63 & 1.92 & 19 \\
\hline & DSGDP & 2.89 & 1.30 & 1.08 & 3.67 & 19 \\
\hline & INTPGDP & 1.14 & 0.49 & 1.05 & 2.77 & 19 \\
\hline \multirow[t]{4}{*}{ Rwanda } & GFCF/GDP & 19.84 & 4.90 & -0.02 & 1.56 & 19 \\
\hline & EXTDGDP & 33.76 & 23.64 & 0.68 & 1.79 & 19 \\
\hline & DSGDP & 1.43 & 0.70 & 0.65 & 2.00 & 19 \\
\hline & INTPGDP & 0.48 & 0.27 & 0.60 & 2.46 & 19 \\
\hline \multirow[t]{4}{*}{ Tanzania } & GFCF/GDP & 29.56 & 5.91 & -0.86 & 2.24 & 18 \\
\hline & EXTDGDP & 25.15 & 10.68 & 0.61 & 1.78 & 19 \\
\hline & DSGDP & 0.77 & 0.43 & 1.12 & 3.32 & 19 \\
\hline & INTPGDP & 0.28 & 0.09 & 0.52 & 2.29 & 19 \\
\hline \multirow[t]{4}{*}{ Uganda } & GFCF/GDP & 22.65 & 2.34 & 0.16 & 2.21 & 19 \\
\hline & EXTDGDP & 27.14 & 20.05 & 0.79 & 1.89 & 19 \\
\hline & DSGDP & 0.94 & 0.74 & 1.20 & 3.81 & 19 \\
\hline & INTPGDP & 0.27 & 0.17 & 0.80 & 2.88 & 19 \\
\hline \multirow[t]{4}{*}{ All } & GFCF/GDP & 21.41 & 6.48 & 0.18 & 2.51 & 227 \\
\hline & EXTDGDP & 26.22 & 24.78 & 1.94 & 7.48 & 228 \\
\hline & DSGDP & 3.47 & 5.87 & 4.15 & 24.50 & 228 \\
\hline & INTPGDP & 0.72 & 0.73 & 2.32 & 10.12 & 228 \\
\hline
\end{tabular}


GFCFGDP
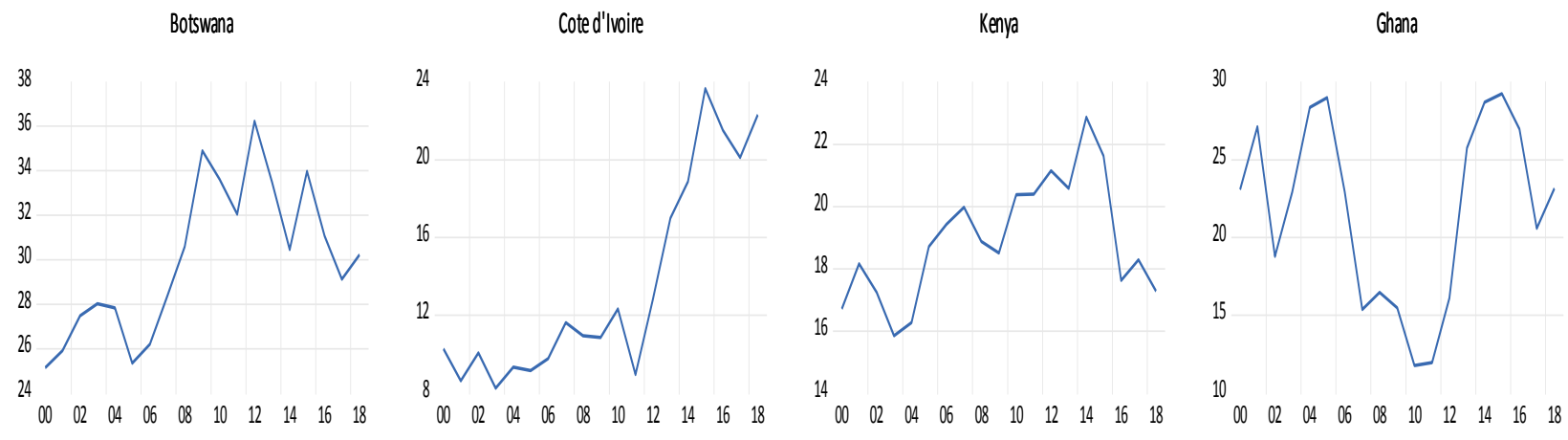

Gabon

Maunitus

Malawi

36

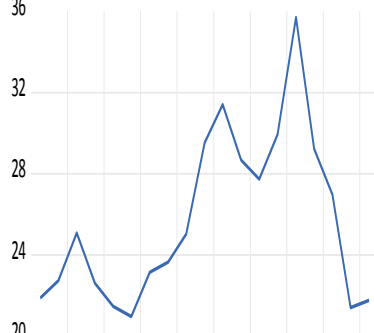

20

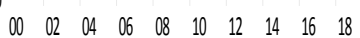

SA

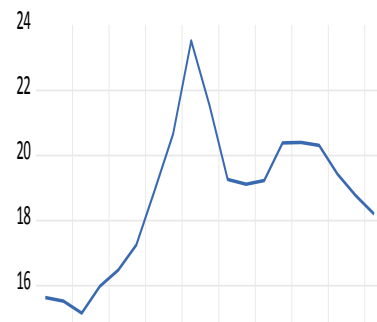

14

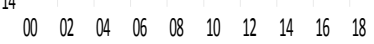

Figure 1.

Gross fixed capital formation (\% of GDP) for the individual countries.

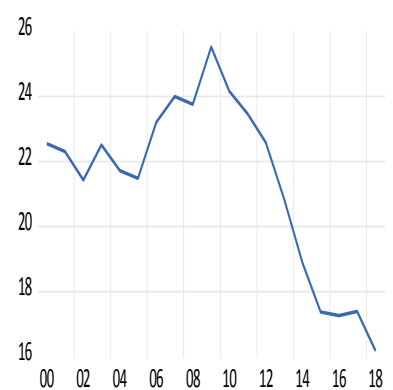

Rwanda

28

24

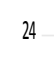

20

16
24

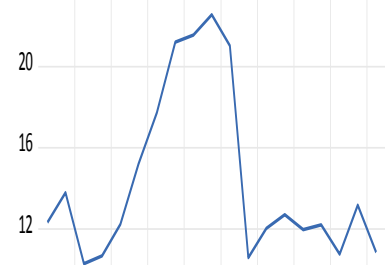

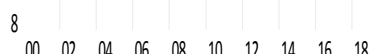

Uganda

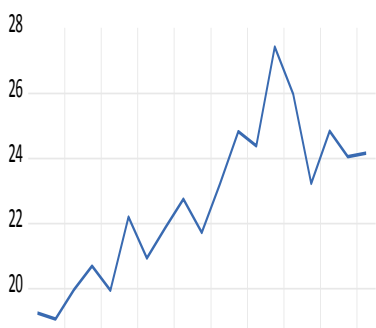

Nigeria

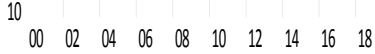

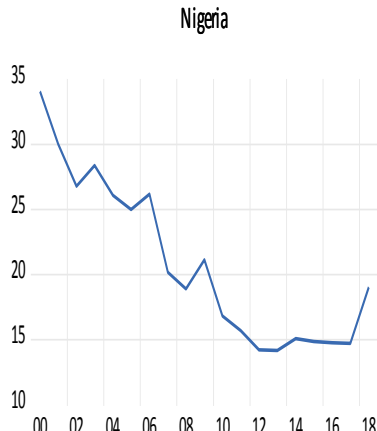

Tanzania

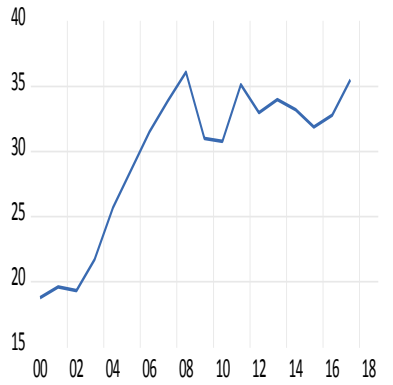


EXTDGDP

Botswana

14

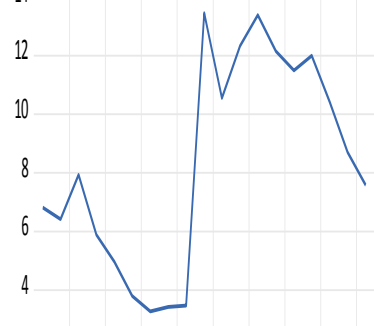

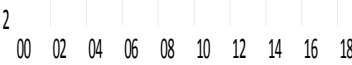

Gabon

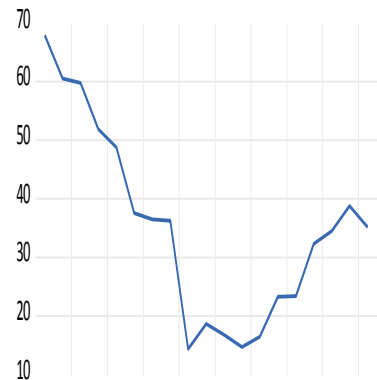

$\begin{array}{llllllllll}00 & 02 & 04 & 06 & 08 & 10 & 12 & 14 & 16 & 18\end{array}$

SA

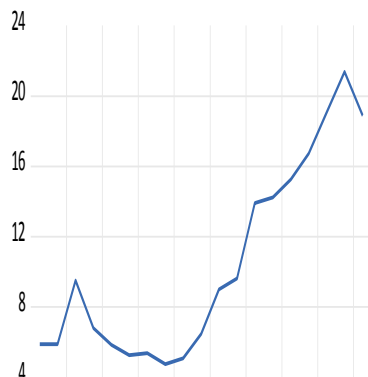

$\begin{array}{llllllllll}400 & 02 & 04 & 06 & 08 & 10 & 12 & 14 & 16 & 18\end{array}$

$\begin{array}{ccc}00 & 02 \quad 04 \\ \text { Figure } 2 .\end{array}$
Coted"lvoire

100

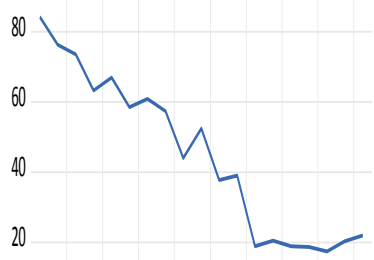

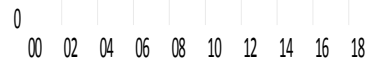

Maunitus

12

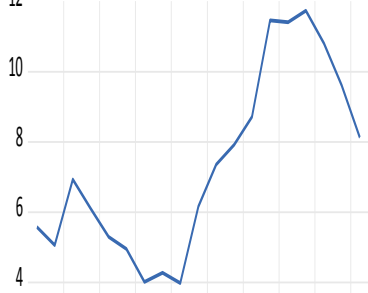

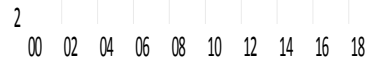

Rwanda

80

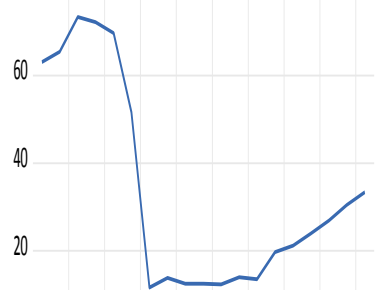

$\begin{array}{llllllllll}0 & 02 & 04 & 06 & 08 & 10 & 12 & 14 & 16 & 18\end{array}$

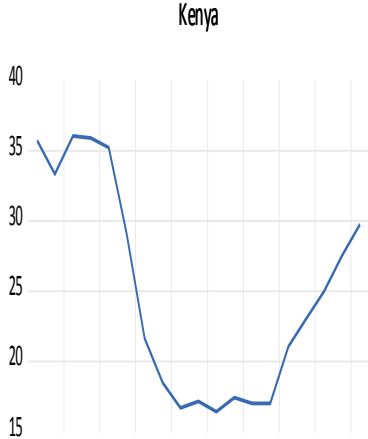

$\begin{array}{llllllllll}15 & 00 & 02 & 04 & 06 & 08 & 10 & 12 & 14 & 16\end{array}$

Malawi

160

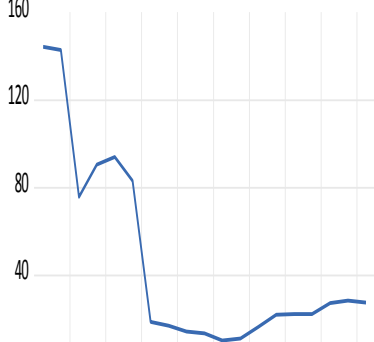

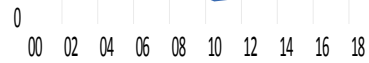

Uganda

80

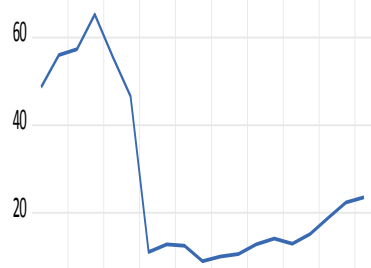

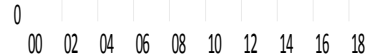

Ghana

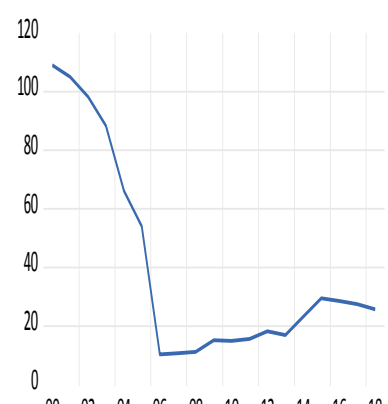

Nigeria
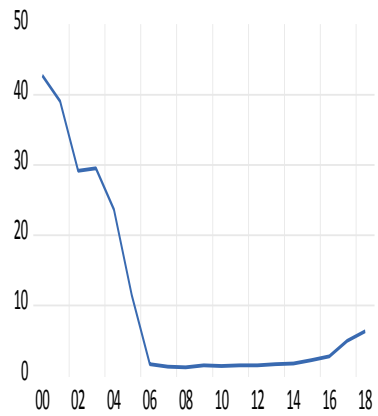

Tanzania

50

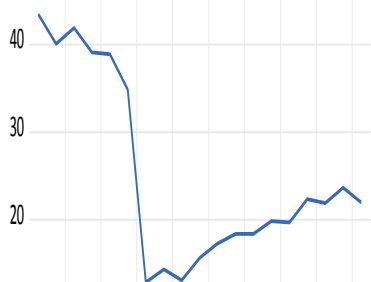

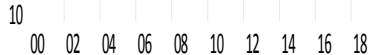

External debt stock (\% of GDP) for the individual countries. 
DSGDP

Botwana

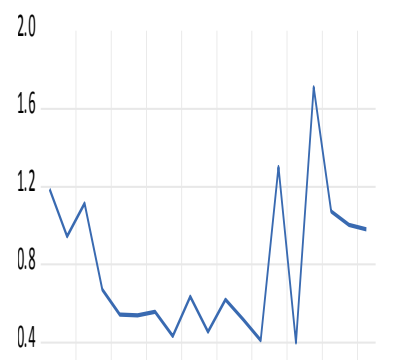

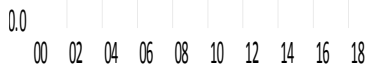

Gabon

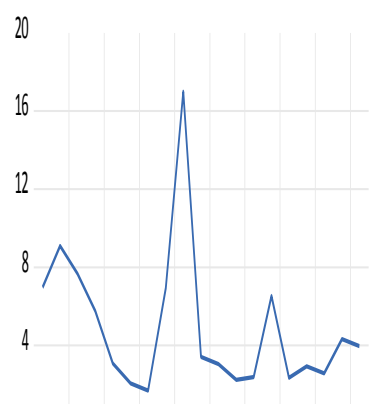

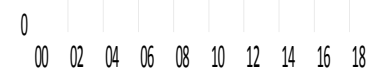

SA

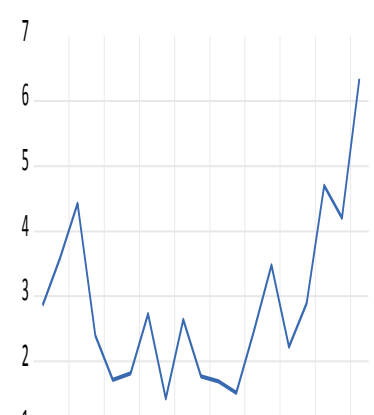

1

$\begin{array}{llllllllll}00 & 02 & 04 & 06 & 08 & 10 & 12 & 14 & 16 & 18\end{array}$

Figure 3.

Debt service on external debt (\% GDP) for the individual countries.
Kenpa

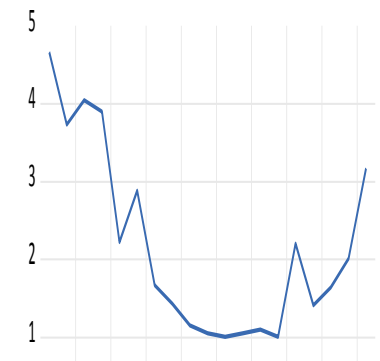

$\begin{array}{llllllllll}0 & 02 & 04 & 06 & 08 & 10 & 12 & 14 & 16 & 18\end{array}$

Maawi

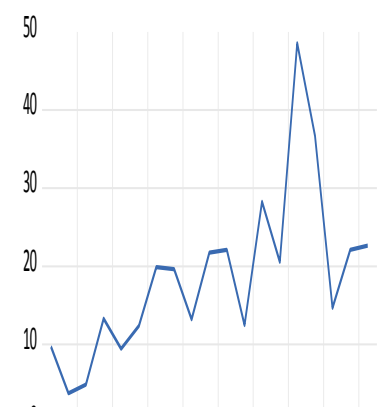

$\begin{array}{llllllllll}0 & 02 & 04 & 06 & 08 & 10 & 12 & 14 & 16 & 18\end{array}$

Rwanda

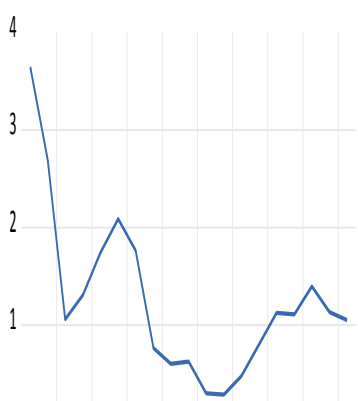

$\begin{array}{llllllllll}0 & 02 & 04 & 06 & 08 & 10 & 12 & 14 & 16 & 18\end{array}$

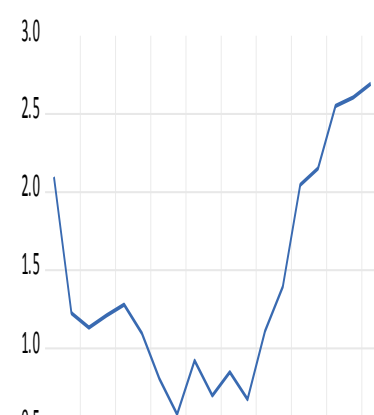

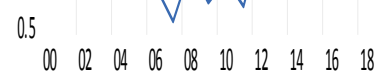

Uganda

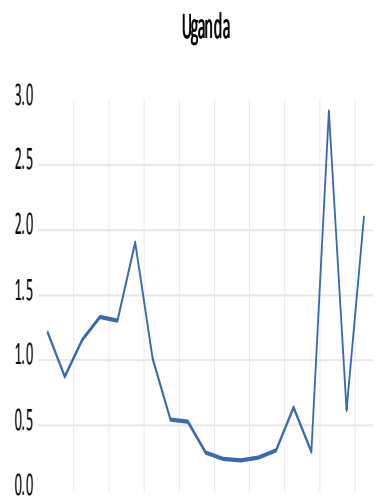

$\begin{array}{llllllllll}00 & 02 & 04 & 06 & 08 & 10 & 12 & 14 & 16 & 18\end{array}$
Ghana

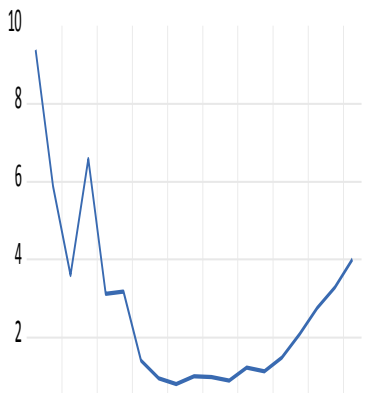

$\begin{array}{llllllllll}00 & 02 & 04 & 06 & 08 & 10 & 12 & 14 & 16 & 18\end{array}$

Nigeria

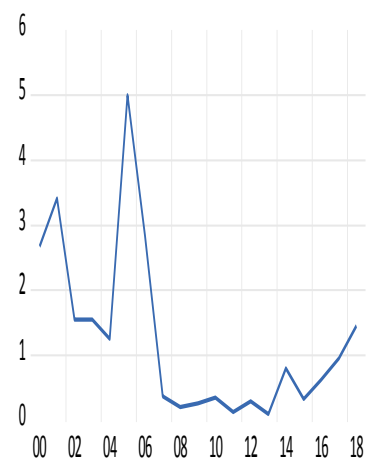

Tanzania

20

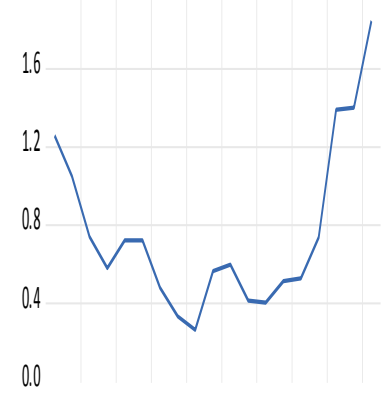


INTPGDP
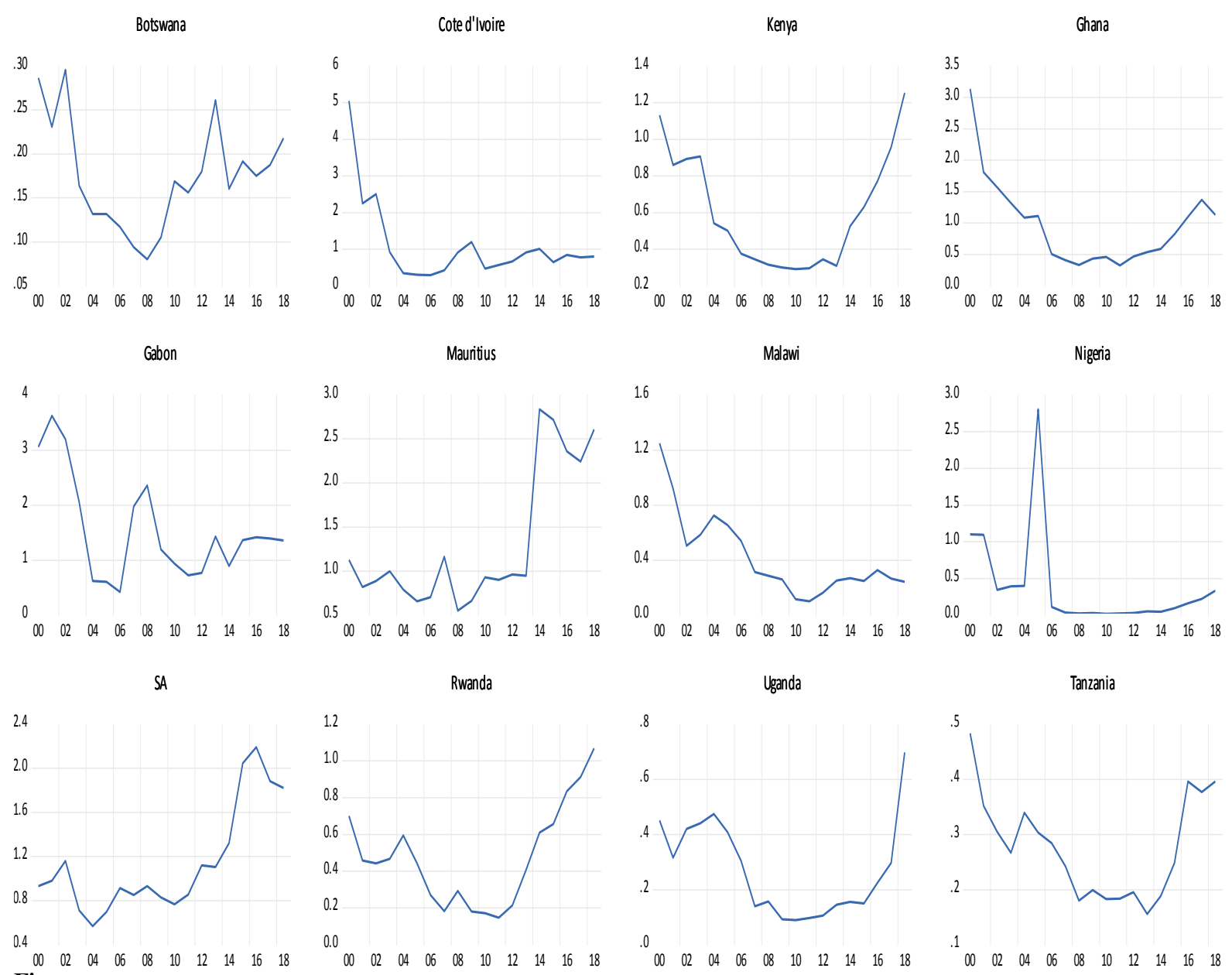

Figure 4.

Interest payments on external debts (\% of GDP) for the individual countries.

\subsection{Model Specification}

As stated previously, this paper employs the pooled mean group (PMG) framework to analyze the impact of public debt on capital formation. This empirical approach, which is proposed by Pesaran, Shin, \& Smith (1999), is appropriate for this study since our main objective is to provide both the short-run and long-run estimates of the impact of public debt on capital formation. Also, according to Ahmad, Etudaiye-Muhtar, Matemilola, \& Bany-Ariffin (2016), the PMG is especially appropriate for panel data with longer time periods. Another advantage of this framework is that, although it imposes the same long-run results for different countries, it also estimates different short-run coefficients for different countries, thereby allowing a country-by-country comparison of regression results.

The pooled mean group (PMG) model for the impact of public debts on capital formation is specified in logarithmic form as follows:

$$
\begin{aligned}
& \triangle L G F C F G D P_{i t}=\phi_{i}\left(\text { LGFCFGDP }_{i t-1}-\beta_{1} L_{E X T D G D P}-\beta_{2} L D S G D P_{i t}-\beta_{3} L_{I N T P G D P}-\beta_{0}\right) \\
& +\lambda_{1} \Delta L E X T D G D P_{i t}+\lambda_{2} \Delta L D S G D P_{i t}+\lambda_{3} \Delta L I N T P G D P_{i t}+\gamma_{i}+u_{i t}
\end{aligned}
$$

Where LGFCFGDP = gross fixed capital formation, LEXTDGDP = external debt stock, and LINTPGDP $=$ interest payments on external debts. All variables in the capital formation model are expressed as a ratio of GDP and are also log-transformed. Further, while $\beta_{i}(i=1,2, \ldots n)$ represent the 
long-run coefficients, $\lambda_{i}(i=1,2, \ldots n)$ are the short-run coefficients. Also, $u_{i t}$ is the regression residuals, while $\phi_{i}$ is the error correction term, which captures the speed at which short-run deviations from the long-run equilibrium are corrected. We expect this coefficient to be negatively signed so that the relationship between public debt and capital formation would be stable in the long run.

\section{Data Analysis}

Tables 2 and 3 show the pooled mean group (PMG) results for the impact of public debt on capital formation. For a plausible specification, we follow the rule of thumb by allowing only one lagged term for all variables since our data frequency is annual. The model selection is also confirmed empirically using the Schwarz information criterion (SIC), which selects the ARDL (1, 1, 1, 1). This implies that the most plausible pooled mean group model is one that incorporates one lagged value of capital formation and each of the three public debt variables (LEXTDGDP, LDSGDP and LINTPGDP) as additional explanatory variables.

Table 2.

Long-run and short-run results for the pooled data

\begin{tabular}{l|c|c}
\hline Variables & Short-run Coefficients & Long-run Coefficients \\
\hline $\boldsymbol{E C T}_{\boldsymbol{t}-\mathbf{1}}$ & -0.2601 & - \\
\hline LEXTDGDP & $(0.0002)$ & -0.2741 \\
& 0.0057 & $(0.0000)$ \\
\hline LDSGDP & $(0.8353)$ & 0.0946 \\
& -0.0013 & $(0.0539)$ \\
\hline LINTPGDP & $(0.9565)$ & -0.0603 \\
& 0.0461 & $(0.2845)$ \\
\hline Constant & $(0.0761)$ & - \\
\hline
\end{tabular}

\subsection{PMG Common Coefficients for Sub-Saharan Africa}

Table 2 shows the common coefficients (short-run and long-run) for the 12 Sub-Saharan countries. We can see that the speed of adjustment coefficient has the expected negative sign and is highly statistically significant, suggesting that the gross fixed capital formation model would achieve long-run convergence even after suffering short-run deviations.

The coefficient of -0.2741 shows that the speed at which short-term deviations is corrected is about $27 \%$ per year. The short-run coefficient for LEXDGDP is positive, small and statistically insignificant, suggesting that increasing public external debt level has no real effect on capital formation in the short run. This is consistent with Ricardian equivalence theory; hence it shows that the choice between public debt and taxation in financing fiscal deficit has no short-run economic implications in Sub-Saharan Africa. However, the positive short-run coefficient contradicts Nautet \& Van Meensel (2011) and Akram (2011).

Further, the estimated short-run coefficient for LDSGDP is also small, negative and statistically insignificant.

The lack of significance of this coefficient shows that increasing debt service burden resulting from rising external debt stock has no significant effect on capital formation in the short run. This finding agrees with the Ricardian equivalence theory as well as Akram (2011), who found that debt service has no significant effect on investment. However, the negative sign associated with LDSGDP tends to be consistent with the claim by Bhattacharya \& Clements (2004), that higher debt service has a crowding out effect on both private investment and human capital formation. 
Finally, the estimated short-run coefficient for LINTPGDP indicates that interest payment relative to nominal GDP has a positive and weakly significant effect on capital formation. This positive coefficient implies that higher interest payment leads to higher capital formation. In other words, the higher the interest payment burden due to higher interest rates on public debt, the higher the accumulated gross fixed capital formation. This finding, however, contradicts the crowding out theory.

For long-run results, we can see that the coefficient for LEXTDGDP is negative and significant at the $1 \%$ level, which is consistent with the debt overhang theory.

Specifically, the coefficient of -0.2741 shows that, ceteris paribus, a $1 \%$ increase in the external debt stock would, on average, increase gross fixed capital formation by approximately $0.27 \%$ in the long run. This also implies that SSA countries have been suffering from debt overhang since 2000 when the current millennium began, which explains the low level of capital formation or capital investment the sub-region has recorded so far. Further, although the coefficient for LINTPGDP is small at -0.0603 and statistically insignificant, its negative sign signals that higher interest payment on external debt can also lead to debt overhang problems and/or crowding out effects in the long run. This, therefore, serves as a warning to SSA governments against the long-term dangers of increasing reliance on external debts to finance fiscal deficits. These findings are consistent with Chowdhury (2001); Islam \& Hasan (2007); Okoye et al. (2017) and Whajah et al. (2019). On the contrary, the long-run coefficient for LDSGDP is positive and significant at the $5 \%$ level, indicating that debt service has a beneficial effect in the long run. However, this contradicts both the debt overhang theory and the findings of Akram (2011).

\subsection{PMG Differential Short-Run Coefficients}

Table 3 shows the short-run results for the individual countries. As this table shows, the error correction term has a negative sign and is statistically significant (at different levels) for all countries, which is what one would expect if gross fixed capital formation can attain convergence in the long run even after encountering short-run deviations. This confirms that the estimated pooled mean group is stable and significant. However, the speed at which the short-run deviations are corrected varies across countries, ranging from around $4 \%$ to $89 \%$. Also, Kenya, Gabon, Rwanda and Mauritius have the highest adjustment speeds, while Nigeria, Ghana, South Africa and Botswana have the lowest adjustment speeds.

The results also show significant variations in terms of the impacts of different debt measures on capital formation. First, there is evidence that external debt stock has a negative effect in the short run for Côte d'Ivoire, Kenya, Malawi, Nigeria, South Africa and Tanzania, while its short-term effect is positive for Botswana, Ghana, Gabon, Mauritius, Rwanda and Uganda. These differences may reflect the differences in both fiscal policy stance and macroeconomic fundamentals. However, the coefficient for external debt stock is not statistically significant for some countries, namely Kenya, Ghana and Nigeria. Hence, for these countries, increasing external debt level may not have any short-term consequences, which is consistent with Ricardian equivalence theory.

Further, the results show that both debt service and interest payment on external debt have a positive effect on capital formation for Nigeria, South Africa, Rwanda and Uganda, while for others, both debt measures have varied impacts. For Côte d'Ivoire, Kenya, Gabon and Tanzania, external debt service has a negative and significant short-run effect on gross fixed capital formation, while the effect of interest payment on external debt is positive. For Botswana, Ghana, Mauritius and Malawi, the effect of external debt service on gross fixed capital formation is positive, while the effect of interest payment on external debt is negative. However, the effect of interest payment on external debt is statistically insignificant for both Ghana and Malawi.

Journal of Contemporary Research in Business, Economics and Finance
ISSN: 2641-0265
Vol. 3, No. 4, pp. $144-157,2021$
DOI: $10.33094 / 26410265.2021 .34 .144 .157$
C) 2021 by the authors; licensee Learning Gate


Table 3.

Short-run results for individual countries.

\begin{tabular}{|c|c|c|c|c|c|}
\hline Country & $E C T_{t-1}$ & LEXTDGDP & LDSGDP & LINTPGDP & Constant \\
\hline All & $\begin{array}{l}-0.2601 \\
(0.0002)\end{array}$ & $\begin{array}{c}0.0057 \\
(0.8353)\end{array}$ & $\begin{array}{l}-0.0013 \\
(0.9565)\end{array}$ & $\begin{array}{c}0.0461 \\
(0.0761)\end{array}$ & $\begin{array}{c}0.9768 \\
(0.0002)\end{array}$ \\
\hline BOTSWANA & $\begin{array}{l}-0.1185 \\
(0.0001)\end{array}$ & $\begin{array}{c}0.1427 \\
(0.0000)\end{array}$ & $\begin{array}{c}0.0412 \\
(0.0000)\end{array}$ & $\begin{array}{l}-0.0287 \\
(0.0120)\end{array}$ & $\begin{array}{c}0.4680 \\
(0.0038)\end{array}$ \\
\hline CÔTE D'IVOIRE & $\begin{array}{l}-0.1943 \\
(0.0105)\end{array}$ & $\begin{array}{l}-0.1222 \\
(0.0715)\end{array}$ & $\begin{array}{l}-0.1163 \\
(0.0269)\end{array}$ & $\begin{array}{c}0.1260 \\
(0.0047)\end{array}$ & $\begin{array}{l}-0.1943 \\
(0.1851)\end{array}$ \\
\hline KENYA & $\begin{array}{l}-0.8976 \\
(0.0013)\end{array}$ & $\begin{array}{l}-0.0056 \\
(0.8564)\end{array}$ & $\begin{array}{l}-0.0687 \\
(0.0064)\end{array}$ & $\begin{array}{c}0.2085 \\
(0.0038)\end{array}$ & $\begin{array}{c}3.3277 \\
(0.0576) \\
\end{array}$ \\
\hline GHANA & $\begin{array}{l}-0.0958 \\
(0.0115)\end{array}$ & $\begin{array}{c}0.0518 \\
(0.1789)\end{array}$ & $\begin{array}{c}0.1676 \\
(0.0211)\end{array}$ & $\begin{array}{c}-0.0945 \\
(0.2667) \\
\end{array}$ & $\begin{array}{c}0.3765 \\
(0.2407) \\
\end{array}$ \\
\hline GABON & $\begin{array}{l}-0.4982 \\
(0.0002)\end{array}$ & $\begin{array}{c}0.0695 \\
(0.0035) \\
\end{array}$ & $\begin{array}{l}-0.1157 \\
(0.0000)\end{array}$ & $\begin{array}{c}0.0976 \\
(0.0002) \\
\end{array}$ & $\begin{array}{c}2.0263 \\
(0.0108) \\
\end{array}$ \\
\hline MAURITIUS & $\begin{array}{l}-0.2928 \\
(0.0004)\end{array}$ & $\begin{array}{c}0.1022 \\
(0.0004)\end{array}$ & $\begin{array}{c}0.0198 \\
(0.0000)\end{array}$ & $\begin{array}{l}-0.0413 \\
(0.0000)\end{array}$ & $\begin{array}{c}0.9602 \\
(0.0151)\end{array}$ \\
\hline MALAWI & $\begin{array}{l}-0.2535 \\
(0.0526)\end{array}$ & $\begin{array}{l}-0.0912 \\
(0.0176)\end{array}$ & $\begin{array}{c}0.0682 \\
(0.5896) \\
\end{array}$ & $\begin{array}{l}-0.0355 \\
(0.8682) \\
\end{array}$ & $\begin{array}{c}0.8738 \\
(0.4383) \\
\end{array}$ \\
\hline NIGERIA & $\begin{array}{l}-0.0381 \\
(0.0004)\end{array}$ & $\begin{array}{l}-0.0019 \\
(0.6909) \\
\end{array}$ & $\begin{array}{c}0.0423 \\
(0.0000) \\
\end{array}$ & $\begin{array}{c}0.0042 \\
(0.0483) \\
\end{array}$ & $\begin{array}{c}0.0942 \\
(0.0281) \\
\end{array}$ \\
\hline SOUTH AFRICA & $\begin{array}{l}-0.1048 \\
(0.0000)\end{array}$ & $\begin{array}{l}-0.1766 \\
(0.0000)\end{array}$ & $\begin{array}{c}0.0248 \\
(0.0001)\end{array}$ & $\begin{array}{c}0.0985 \\
(0.0001)\end{array}$ & $\begin{array}{c}0.3767 \\
(0.0008)\end{array}$ \\
\hline RWANDA & $\begin{array}{l}-0.3213 \\
(0.0000)\end{array}$ & $\begin{array}{c}0.0642 \\
(0.0000)\end{array}$ & $\begin{array}{c}0.0192 \\
(0.1584)\end{array}$ & $\begin{array}{c}0.1203 \\
(0.0007)\end{array}$ & $\begin{array}{c}1.2368 \\
(0.0005) \\
\end{array}$ \\
\hline UGANDA & $\begin{array}{l}-0.1524 \\
(0.0010)\end{array}$ & $\begin{array}{c}0.0584 \\
(0.0000)\end{array}$ & $\begin{array}{c}0.0217 \\
(0.0000) \\
\end{array}$ & $\begin{array}{c}0.0097 \\
(0.0207) \\
\end{array}$ & $\begin{array}{c}0.6056 \\
(0.0416) \\
\end{array}$ \\
\hline TANZANIA & $\begin{array}{l}-0.1543 \\
(0.0025)\end{array}$ & $\begin{array}{l}-0.0224 \\
(0.0180)\end{array}$ & $\begin{array}{l}-0.1205 \\
(0.0001)\end{array}$ & $\begin{array}{c}0.0893 \\
(0.0027) \\
\end{array}$ & $\begin{array}{c}0.6817 \\
(0.0986) \\
\end{array}$ \\
\hline
\end{tabular}

\section{Conclusions}

This paper contributes to the debt sustainability literature by examining the effects of public debts on capital formation in the Sub-Saharan African (SSA) region using the pooled mean group estimation approach. The study focuses on 12 countries, namely Botswana, Côte d'Ivoire, Kenya, Ghana, Gabon, Mauritius, Malawi, Nigeria, South Africa, Rwanda, Uganda and Tanzania. The debt variables considered are external debt stock, debt service on external debt and interest payment on external debt, and the study period covered spans from 2000 to 2018. The empirical analysis is based on annual data in logarithmic form. There is evidence that SSA countries have a common long-run convergence in terms of the relationship between public debts and capital formation. However, the results generally suggest that increasing external debt stock and interest payment on external debts would not have any impact on capital formation in the short run but would exert a serious negative effect in the long run. Hence, there would be a debt overhang problem in SSA if the individual countries continue to rely heavily on external debt to finance fiscal deficits. This has a serious policy implication given that most of the countries in this economic sub-region are already borrowing heavily to cushion the effect of the looming recession due to the impact of COVID-19. Therefore, increasing government revenue base, minimizing economic waste associated with public expenditure, and intensifying negotiations for debt relief may be a plausible way out. There is evidence that external debt service has no significant effect on capital formation in the short run, but its impact is positive and weakly significant in the long run. This implies that, contrary to Bhattacharya \& Clements (2004), the SSA countries are not neglecting investments in 
critical infrastructures needed to drive growth, which explains the positive long-term effect of external debt service on capital formation despite being faced with a huge debt service burden resulting from large external debt stock.

\section{References}

Abdullahi, M. M., Hassan, S. B., \& Bakar, N. A. B. A. (2016). Analyzing the impact of external debt on capital formation in Nigeria: An autoregressive distributed lag approach. Mediterranean Journal of Social Sciences, 7(1), 173-183.

Ahamefula, A. N. (2015). Public debt and infrastructure provision in Nigeria: An econometric analyses (1981-2012). Unpublished, MSc Dissertation Submitted to the Department of Finance and Banking University of Port Harcourt, Nigeria.

Ahmad, R. O., Etudaiye-Muhtar, F., Matemilola, B. T., \& Bany-Ariffin, A. N. (2016). Financial market development, global financial crisis and economic growth: Evidence from developing nations. Portuguese Economic Journal, 15(2), $199-214$.

Ahmed, H., \& Miller, S. M. (2000). Crowding-out and crowding-in effects of the components of government expenditure. Contemporary Economic Policy, 18(1), 124-133. Available at: https://doi.org/10.1111/j.1465-7287.2000.tbo0011.x.

Akram, N. (2011). Impact of public debt on the economic growth of Pakistan. The Pakistan Development Review, 50(4), 599-615.

Bal, D. P. (2014). The effects of public debt on capital formation in India: Evidence from structural VAR analysis. International Journal of Monetary Economics and Finance, 7(1), 66-80.

Baum, A., Checherita-Westphal, C., \& Rother, P. (2012). Debt and growth: New evidence for the Euro Area. European Central Bank. Working Paper Series, No. 1450.

Bhattacharya, R., \& Clements, B. (2004). Calculating the benefits of debt relief. Finance \& Development, 41(4), 48-50.

Carlson, K., \& Spencer, R. W. (1975). Crowding out and its critics. Federal Reserve Bank of St. Louis Review, 57, 2-17. Available at: https://doi.org/10.20955/r.57.2-17.nkq.

Chowdhury, A. R. (2001). External debt and growth in developing countries: A sensitivity and causal analysis. WIDER Discussion Paper No. 2001/95, World Institute for Development Economics Research, United Nations University.

De Leeuw, F., \& Holloway, T. M. (1983). Cyclical adjustment of the federal budget and federal debt. Survey of Current Business, $63(12), 25-40$.

Filip, B. F. (2019). Determinants of public debt. The case of the European Union countries. Theoretical and Applied Economics, 26(Special), 61-70.

Islam, M. F., \& Hasan, M. S. (2007). The macroeconomic effects of government debt on capital formation in the United States: An empirical investigation. The Manchester School, 75(5), 598-616.

Kazmi, A. A. (2001). Ricardian equivalence hypothesis: Some empirical tests for Pakistan based on Blanchard-Evans models. The Pakistan Development Review, 31(4), 743-758.

Kharusi, S. A., \& Ada, M. S. (2018). External debt and economic growth: The case of emerging economy. Journal of Economic Integration, 33(1), 1141-1157.

Krugman, P. (1988). Financing vs. forgiving a debt overhang. Journal of Development Economics, 29(3), 253-268. Available at: https://doi.org/10.1016/0304-3878(88)90044-2.

Kwoba, P. L., \& Kosimbei, G. (2015). Public debt and economic growth in the east African community. Economics and Finance Review, 4(5), 31-39.

Mencinger, J., Aristovnik, A., \& Verbic, M. (2014). The impact of growing public debt on economic growth in the European Union. Amfiteatru Economic Journal, $16(35), 403-414$.

Nautet, M., \& Van Meensel, L. (2011). Economic impact of the public debt. National Bank of Belgium Economic Revierw, 2(1), 7-19.

Okoye, L. U., Modebe, N. J., ERIN, O., \& Evbuomwan, G. O. (2017). Effect of external debt on economic growth: Evidence from Nigeria. Sustainable Economic Growth, Education Excellence, and Innovation Management through Vision, $20(2), 4046$ -4058 .

Pesaran, M. H., Shin, Y., \& Smith, R. P. (1999). Pooled mean group estimation of dynamic heterogeneous panels. Journal of the American Statistical Association, 94(446), 62 1-634. Available at: https://doi.org/10.1080/0162 1459.1999.10474156.

Reinhart, C. M., Reinhart, V. R., \& Rogoff, K. S. (2012). Public debt overhangs: Advanced-economy episodes since 1800. Journal of Economic Perspectives, 26(3), 69-86. Available at: https://doi.org/10.1257/jep.26.3.69.

Thao, P. T. P. (2018). Impacts of public debt on economic growth in six ASEAN countries. Ritsumeikan Annual Review of International Studies, 17(3), 63-88.

Whajah, J., Bokpin, G. A., \& Kuttu, S. (2019). Government size, public debt and inclusive growth in Africa. Research in International Business and Finance, 49, 225-240. Available at: https://doi.org/10.1016/j.ribaf.2019.03.008. 